\title{
Tissue flow and biomass production of piatã grass in function of defoliation frequency and nitrogen fertilization
}

Bruna Biava de Menezes ${ }^{1}$, Luísa Melville Paiva ${ }^{2}$, Patrick Bezerra Fernandes ${ }^{1}$, Nathália Rafaela Fidelis Campos $^{1}$, Rodrigo Amorim Barbosa ${ }^{3}$, Anderson Luiz de Lucca Bento ${ }^{1}$, Raizza Fátima Abadía Tulux Rocha ${ }^{1}$, Maria da Graça Morais ${ }^{1}$

${ }^{1}$ Universidade Federal do Mato Grosso do Sul - UFMS, MS. ${ }^{2}$ Universidade Estadual do Mato Grosso do Sul - UEMS, MS. ${ }^{3}$ Empresa Brasileira de Pesquisa Agropecuária - Gado de Corte, Campo Grande, MS. E-mail: zoo.patrick@hotmail.com

\begin{abstract}
Due to the multifactorial aspect between the morphogenetic, morphological and agronomic characteristics of the forage plants, it is necessary to look for management options that increase the production and the utilization of the mass of forage submitted to different frequencies of defoliation and nitrogen levels. The objective of this study was to verify the effects of two defoliation frequencies and two levels of nitrogen applied in a single dose on the morphogenetic, structural and forage production of piatan grass in the water period. The work was carried out in the agrostological field of the Faculty of Veterinary Medicine and Animal Science (UFMS), Campo Grande - MS. The experimental area was composed of 12 plots of $18 \mathrm{~m}^{2}$ each of Brachiaria brizantha cv. Piatã (Syn. Urochloa brizantha cv. Piatã). The experimental design was completely randomized and the treatments consisted of two defoliation frequencies (with cut intervals of 28 and 35 days) and single application of two levels of nitrogen (100 and $200 \mathrm{~kg} \mathrm{ha}^{-1}$ of $\mathrm{N}$, in the form of urea) . Therefore, piatan grass pastures can be managed with a single fertilization of $100 \mathrm{~kg} \mathrm{ha}^{-1}$ of N, with height close to $30 \mathrm{~cm}$, as the production of leaf blades is not compromised. The single application of high doses of $\mathrm{N}$ does not increase the number, but raises the individual weights of existing tillers without affecting the morphogenic and morphological characteristics of the forage canopy. For pastures of piatã grass established in soils of good fertility it is recommended as a management strategy to use $20 \mathrm{~cm}$ as minimum height of cut or grazing and frequency of with interval of 28 days and height of approximately 30 $\mathrm{cm}$. In established pastures, in the water period, if it is desired to reduce the dose fractionation of $\mathrm{N}$, it is recommended as a single application the dose of up to $100 \mathrm{~kg}$ of $\mathrm{N} \mathrm{ha}{ }^{-1}$ immediately after the first cut.
\end{abstract}

Keywords: leaf area; pasture; tiller.

Fluxo de tecidos e produção de biomassa do capim-piatã em função da frequência de desfolhação e adubação nitrogenada

\section{RESUMO}

Devido ao aspecto multifatorial entre as características morfogênicas, morfológicas e agronômicas das plantas forrageiras, torna-se necessário buscar opções de manejo que aumentem a produção e o aproveitamento da massa de forragem submetida a diferentes frequências de desfolhação e níveis de nitrogênio. Objetivou-se verificar os efeitos de duas frequências de desfolhação e de dois níveis de nitrogênio aplicados em dose única sobre as características morfogênicas, estruturais e produção de forragem do capim-piatã no período das águas. O trabalho foi realizado no campo agrostológico da Faculdade de Medicina Veterinária e Zootecnia (UFMS), Campo Grande - MS. A área experimental foi composta de 12 parcelas de $18 \mathrm{~m}^{2}$ cada de Brachiaria brizantha cv. Piatã (Syn. Urochloa brizantha cv. Piatã). O delineamento experimental utilizado foi inteiramente casualizado e os tratamentos consistiram em duas frequências de desfolhação (com intervalos de cortes de 28 e 35 dias) e aplicação única de dois níveis de nitrogênio (100 e $200 \mathrm{~kg} \mathrm{ha}^{-1} \mathrm{de} \mathrm{N}$, na forma de ureia). Diante disso, pastos de capim-piatã podem ser manejados com uma única adubação de $100 \mathrm{~kg} \mathrm{ha}^{-1} \mathrm{de} \mathrm{N}$, com altura próxima aos $30 \mathrm{~cm}$, pois a 
produção de lâminas foliares não é comprometida. A aplicação única de doses elevadas de $\mathrm{N}$ não aumenta o número, mas eleva o peso individual dos perfilhos existentes sem afetar as características morfogênicas e morfológicas do dossel forrageiro. Para pastos de capim-piatã estabelecidos em solos de boa fertilidade recomenda-se como estratégia de manejo usar $20 \mathrm{~cm}$ como altura mínima de corte ou pastejo e frequência de com intervalo de 28 dias e altura aproximada de $30 \mathrm{~cm}$. Em pastos estabelecidos, no período das águas, caso se deseja reduzir o fracionamento da dose de $\mathrm{N}$, recomenda-se como aplicação única a dose de até $100 \mathrm{~kg}$ de $\mathrm{N} \mathrm{ha}^{-1}$ imediatamente após a realização do primeiro corte.

Palavras-chave: área foliar; pasto; perfilho.

\section{Introduction}

Nitrogen fertilization promotes greater accumulation of biomass and accelerates the tissue flow of forage grasses (LEMAIRE et al., 2009), but it should be accompanied by management techniques that allow efficient cutting of the forage produced. Otherwise large forage losses can occur through senescence due to the shorter lifetime of the leaf blade and higher pseudostem accumulation, thus diminishing the nutritional value of the sward (PACIULLO et al., 2016). The general recommendation is to apply nitrogen as top dressing in moist soil with moderate temperature, in fractionated form $\left(50 \mathrm{~kg} \mathrm{~N} \mathrm{ha}{ }^{-1}\right.$ /each time). However, little is known about the maximum capacity to use $\mathrm{N}$ per application and how high single doses can impair the morphogenic and structural variables of forage grasses.

Management proposals based on alterations of defoliation frequency result in fluctuations in the plastic response of grasses, because they condition the plant to adapt according to the environmental variables (DIFANTE et al., 2011). Since more intensive or less severe defoliations induce modifications in the quantity and quality of light falling on the leaf blades nearest the soil (DEREGIBUS et al., 1985), this causes fluctuations in the tillering dynamics (LEMAIRE; AGNUSDEI, 2000).

However, irrespective of the defoliation frequency, the morphogenic characteristics will present few fluctuations (CHAPMAN; LEMAIRE, 1993; SBRISSIA; SILVA, 2001), because these are genetically determined variables, besides being strongly influenced by temperature and availability of nutrients (LEMAIRE et al. 2009), except in situations where variation occur in light interception (BARBOSA et al., 2011), which can modify the leaf area dynamics of the sward (GASTAL; LEMAIRE, 2015).
Because of the multifactorial interplay of the morphogenic, morphologic and agronomic characteristics of forage plants, it is necessary to find management options that increase the production and utilization of forage mass of grasses submitted to defoliation frequencies and nitrogen levels.

The aim of this study was to assess the effects of two defoliation frequencies and two nitrogen levels applied in a single dose on the morphogenic and structural characteristics and forage production of Piatã grass grown in the rainy season.

\section{Material and Methods}

The experiment was carried out in the agrostological field of the School of Veterinary Medicine and Zootechnics of Mato Grosso do Sul Federal University (UFMS), in Campo Grande, Mato Grosso do Sul, Brazil, with geographic coordinates 2030'32.14"S and 5437'10.41" and altitude of $548 \mathrm{~m}$. The study was conducted from November 2011 to March 2012.

The experimental area was composed of 12 plots with area of $18 \mathrm{~m}^{2}$ each, planted with Brachiaria brizantha cv. Piatã (Syn. Urochloa brizantha cv. Piatã). Soil samples from the experimental area were sent for physical and chemical analysis by a specialized laboratory and presented textural breakdown of $67 \%$ clay, $23 \%$ silt and $10 \%$ sand. The chemical composition is presented in Table 1 . The highly clayey texture of the soil was propitious for fertility due to the high cation exchange capacity (CEC), organic matter content (4.32\%) and $\mathrm{Ca}$ and $\mathrm{Mg}$ saturation, along with the absence of toxic Al. The soil preparation consisted of plowing and two harrowings. Dolomitic limestone was applied at a dose of 3.75 $\mathrm{t} \mathrm{ha}^{-1}$, with $90 \%$ total relative neutralizing power (TRNP). 
Table 1. Results of the chemical analysis of the soil in the experimental area.

\begin{tabular}{cccccccccccc}
\hline \multicolumn{2}{c}{$\mathrm{pH}$} & $\mathrm{P}$ & $\mathrm{OM}$ & $\mathrm{K}$ & $\mathrm{Ca}$ & $\mathrm{Mg}$ & $\mathrm{Al}$ & $\mathrm{H}$ & $\mathrm{S}$ & $\mathrm{CEC}$ & $\mathrm{V}$ \\
\hline $\mathrm{CaCl}_{2}$ & Water & \multicolumn{2}{c}{$\mathrm{mg} \mathrm{dm}^{-3}$} & & \multicolumn{5}{c}{$\mathrm{cmol}_{\mathrm{c}} \mathrm{dm}^{-3}$} \\
\hline 4.71 & 5.31 & 1.69 & 43.17 & 0.28 & 4.6 & 1.85 & 0.34 & 7.05 & 6.73 & 14.12 & 47.66
\end{tabular}

$\mathrm{OM}=$ organic matter; $\mathrm{S}=$ sum of bases $(\mathrm{Ca}, \mathrm{Mg}$ and $\mathrm{K})$; $\mathrm{CEC}=$ cation exchange capacity; $\mathrm{V}=$ base saturation.

For planting, $3 \mathrm{~kg}$ of PSV ha ${ }^{-1}$ was used with continuous distribution of seeds in the row and $20 \mathrm{~cm}$ spacing between rows, with 15 rows per plot and planting depth of $3 \mathrm{~cm}$. For fertilization, $625 \mathrm{~kg} \mathrm{ha}^{-1}$ of single superphosphate and $62.5 \mathrm{~kg} \mathrm{ha}^{-1}$ of urea in the row were applied. Weeds were removed by hoeing.

The experimental design was completely randomized and the treatments consisted of two defoliation frequencies (cutting intervals of 28 and 35 days) and application of a single dose of nitrogen at two levels (100 and $200 \mathrm{~kg} \mathrm{ha}^{-1}$ of $\mathrm{N}$ in the form of urea), with three repetitions per treatment.

At the start of the experiment (November 3,2011 ), the plots were cut uniformly to a height of $20 \mathrm{~cm}$ from the ground with a hedge trimmer, after which the nitrogen dose was applied (100 or
$200 \mathrm{~kg} \mathrm{ha}^{-1}$ ) in the plots previously chosen at random to compose the respective treatments.

The average precipitation was computed from daily readings in the morning of two rain gauges placed at the ends of the plots, at a minimum distance of $50 \mathrm{~m}$ from trees. The minimum and maximum temperatures were obtained from the Weather, Climate and Water Resources Monitoring Center of Mato Grosso do Sul (CEMTEC) in Campo Grande (Figure 1). During the experimental period (November to March), the average maximum temperature was $35.58^{\circ} \mathrm{C}$ and the average minimum was $17.22^{\circ} \mathrm{C}$, without large oscillations. The rainfall in the experimental area was $573.88 \mathrm{~mm}$, distributed uniformly until February.

Figure 1. Rainfall $(\mathrm{mm})$, maximum temperature $\left(\operatorname{Tmax}{ }^{\circ} \mathrm{C}\right)$ and minimum temperature $\left(\operatorname{Tmin}{ }^{\circ} \mathrm{C}\right)$ during the experimental period.

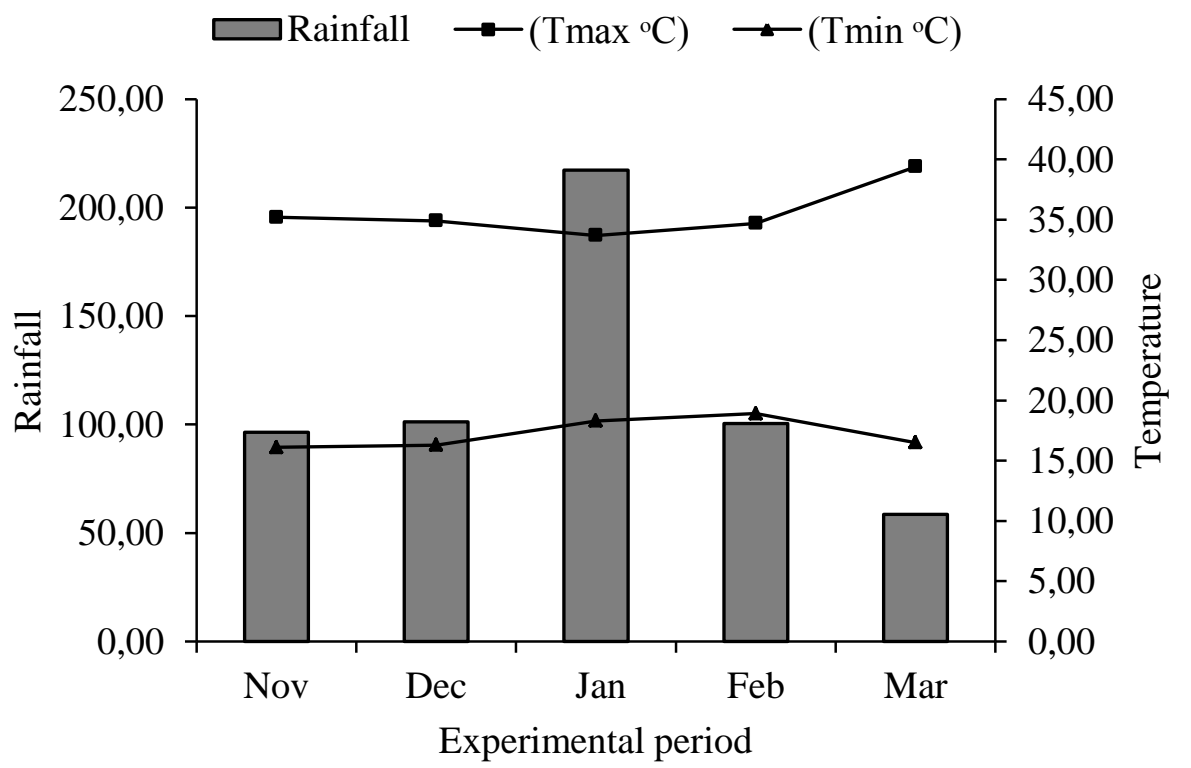

The sward height was measured with a wooden ruler in centimeters, at four points chosen randomly. The height of the grass at each point corresponded to the height of the horizon of the leaves around the ruler markings and the average of these points represented the average height of the plot. The height was measured on cutting days, before sampling of plants from the plots.

The incident light (IL) interception was measured with an AccuPAR Linear PAR/LAI ceptometer, which also provides the leaf area index (LAI). For this purpose, readings were taken at five points at random per plot. At each point, a 
reading was taken above the sward and another at ground level, always being careful that the sensor (at the end of the device) was covered by the grass. The readings were taken in the mornings, between 7 and 10 a.m., because the angle of the sun's rays at that time does not alter the reading.

When the swards reached the heights for cutting, the tiller population density (PD, number of tillers $\left.\mathrm{m}^{-2}\right)$ was estimated by placing a square frame $(1 \mathrm{~m} \times 1 \mathrm{~m})$ randomly within each plot.

The forage mass and morphological components were measured at each cutting by placing the square frame $(1 \mathrm{~m} \times 1 \mathrm{~m})$ on the ground randomly and cutting the grass within the frame with a hedge trimmer to a height of $20 \mathrm{~cm}$ from the ground. These samples were placed in plastic bags, identified and weighed. Each sample was divided into two subsamples. Half was dried and weighed to determine the dry mass (DM), for subsequent estimation of the forage mass (FM), in $\mathrm{kg} \mathrm{DM} \mathrm{ha}{ }^{-1}$. The other half was separated into the morphological components: leaf blade (without sheath), pseudostem (stem + sheath), dead material and inflorescence. The samples were dried in a forced-air oven at $55{ }^{\circ} \mathrm{C}$. The proportion of each morphological component was expressed as a percentage of total weight.

After this sampling, all the rest of the grass was cut to a height of $20 \mathrm{~cm}$ and the trimmings were removed with rakes.

The following procedures were used to evaluate the morphogenic parameters. Four tillers were chosen as representative of each plot and were identified with colored wire, and a wooden stake was placed near each tiller to facilitate location (DAVIES, 1993). Each week the length of the four tillers was measured with a centimeter ruler, and a new tiller was only chosen after cutting the plots or when the tiller died. In each tiller the lengths were measured of the pseudostem (from the ground to the last fully expanded ligula), leaf blade (from the expanded ligula to the end of the blade) and the leaf elongation portion (ligula of the youngest fully expanded leaf to the end of the blade in expansion), and the number of live leaves (NLL, leaves tiller ${ }^{-1}$ ) was counted, considered to be the average number of expanding and expanded leaves per tiller during the evaluation period, excluding the leaves showing signs of senescence in more than $50 \%$ of the length (considered to be dead).
The leaf appearance rate (LAR, leaves tiller $^{-1}$ day $^{-1}$ ) was calculated as the quotient between the number of leaves per tiller and the number of days of the evaluation period. The leaf elongation rate (LEL, $\mathrm{cm}$ leaf blade tiller ${ }^{-1} \mathrm{day}^{-1}$ ) was the quotient of the sum of the increased lengths of the leaf blades, in centimeters, and the number of days in the evaluation period. The stem elongation rate (SER, $\mathrm{cm}_{\text {tiller }}{ }^{-1}$ day $^{-1}$ ) was the quotient between the difference in the pseudostem length at the end and start of the evaluation period and the number of days in that period. The phyllochron (Phylloc, days tiller ${ }^{-1}$ ) was calculated as the time interval between the appearance of two consecutive leaves. It is the inverse of the leaf appearance rate (leaf appearance ${ }^{-1}$ ). Finally, the leaf lifetime (LL, days) was calculated as the time the leaves remained green on the tiller, without any loss by senescence, estimated by the equation $L L=N L L x$ Phylloc (LEMAIRE; CHAPMAN, 1996).

The experiment had a $2 \times 2$ factorial arrangement ( 2 nitrogen levels and 2 defoliation frequencies). The data were submitted to analysis of variance and the Tukey test for multiple comparisons at $5 \%$ significance, using the $R$ program, version 3.0.3 (R CORE TEAM, 2014).

\section{Results and Discussion}

In the experimental situation presented, there is no interaction between levels of fertilization and frequency of defoliation for any of the studied variables.

The nitrogen levels did not influence the sward height, leaf area index and light interception, while the defoliation frequency altered the height and IL (Table 2). The longer cutting interval of 35 days had a significant effect on sward height (increase of $3.17 \mathrm{~cm}$ ) and IL (increase of $3.2 \%$ ) in comparison to the 28-day interval. With the additional 7 days for cutting (from 28 to 35 days), the critical leaf area index (LAIc 95\% IL) was exceeded, while this level was not reached in the shorter interval, and although the differences were small, they were significant. When the cutting occurred after 28 days, the height was slightly lower, at $30.21 \mathrm{~cm}$, and the IL reached $93.10 \%$, very near the LAlc, the moment when the tillers attain maximum elongation of the leaf blade (LB), ideal for defoliation. In this context, the LAlc, monitored by IL, acts as an indicator to define the best moment for animal grazing. 
Table 2. Means of sward height, leaf area index (LAI) and light interception (LI) of Piatã grass.

\begin{tabular}{|c|c|c|c|c|c|c|c|c|}
\hline \multirow[t]{2}{*}{ Variable } & \multicolumn{3}{|c|}{ Fertilization } & \multicolumn{3}{|c|}{ Defoliation Frequency } & \multirow[b]{2}{*}{$\begin{array}{c}\text { P-value } \\
\text { Interaction }\end{array}$} & \multirow[b]{2}{*}{ SEM } \\
\hline & 100 & 200 & P-value & 28 & 35 & P-value & & \\
\hline Height $(\mathrm{cm})$ & 31.25 & 32.35 & 0.342 & $30.21^{\mathrm{b}}$ & $33.38^{\mathrm{a}}$ & 0.019 & 0.597 & 0.692 \\
\hline LAI & 4.70 & 5.08 & 0.293 & 4.88 & 4.90 & 0.962 & 0.812 & 0.156 \\
\hline LI (\%) & 93.78 & 95.61 & 0.112 & $93.10^{b}$ & $96.30^{\mathrm{a}}$ & 0.014 & 0.730 & 0.709 \\
\hline
\end{tabular}

SEM: standard error of the mean; P-value: probability of a significant effect. Means followed by the same upper-case letters in the rows differ by the Tukey test at $5 \%$ probability.

The similarity of the LAl values (Table 2) obtained and the small differences observed for IL and sward height can be explained by the fixed cutting height $(20 \mathrm{~cm})$ utilized in this experiment. In other words, we used the same defoliation intensity for the two cutting frequencies. This management provided similar light infiltration conditions in all the strata of the sward, causing the response dynamics of the different types of tillers to be identical (Table 4). This meant there was no competition for light or nutrients from the soil (Table 1) for the two $\mathrm{N}$ levels and for the two cutting intervals (BARBOSA et al., 2012; GASTAL; LEMAIRE, 2015: LARA; PEDREIRA 2011; MONTAGNER et al., 2011).

The defoliation frequency only increased $(P<0.05)$ the LEL (Table 3), in favor of defoliation with 28-day interval, possibly due to the presence of more LB in expansion, i.e., more leaves in expansion than leaves already expanded, at which point growth stops and senescence starts. The increase of the LEL was reflected in the structural trait NLL (Table 4), where a significant increase was detected for defoliation after 28 days. These results support the evidence that cutting one week sooner improves the nutritive value of the biomass. Since there were no large differences in sward height and FM (Table 5), this management strategy will enhance grazing efficiency and increase the number of grazing cycles (BARBOSA et al., 2007).

Table 3. Flow of tissues in Piatã grass swards.

\begin{tabular}{|c|c|c|c|c|c|c|c|c|}
\hline \multirow[b]{2}{*}{ Variable } & \multicolumn{3}{|c|}{ Fertilization } & \multicolumn{3}{|c|}{ Defoliation Frequency } & \multirow[b]{2}{*}{$\begin{array}{c}\text { P-value } \\
\text { Interaction }\end{array}$} & \multirow[b]{2}{*}{ SEM } \\
\hline & 100 & 200 & P-value & 28 & 35 & P-value & & \\
\hline${ }^{1}$ LAR & 0.085 & 0.088 & 0.674 & 0.086 & 0.086 & 0.999 & 0.674 & 0.003 \\
\hline${ }^{2} \mathrm{SER}$ & 0.111 & 0.113 & 0.918 & 0.123 & 0.101 & 0.207 & 0.110 & 0.008 \\
\hline${ }^{3} \mathrm{LEL}$ & 1.76 & 1.69 & 0.638 & $1.90^{\mathrm{a}}$ & $1.55^{\mathrm{b}}$ & 0.040 & 0.733 & 0.083 \\
\hline${ }^{4}$ Phylloc & 10.21 & 11.69 & 0.186 & 10.88 & 11.02 & 0.895 & 0.346 & 0.512 \\
\hline${ }^{5} \mathrm{LL}$ & 54.48 & 57.66 & 0.488 & 57.70 & 54.43 & 0.477 & 0.839 & 1.99 \\
\hline
\end{tabular}

${ }^{1}$ Leaf appearance rate (leaves tiller $\left.{ }^{-1} \mathrm{day}^{-1}\right) ;{ }^{2}$ stem elongation rate $\left(\mathrm{cm}\right.$ tiller ${ }^{-1}$ day $\left.^{-1}\right) ;{ }^{3}$ leaf elongation rate $(\mathrm{cm}$ of leaf blade tiller ${ }^{-1}$ day $^{-1}$ ); ${ }^{4}$ Phyllochrome (days. leaf tiller ${ }^{-1}$ ); ${ }^{5}$ leaf lifetime (LL. days); SEM: standard error of the mean; Pvalue: probability of a significant effect. Means followed by the same lower-case letters in the row differ by the Tukey test at $5 \%$ probability. 
Table 4. Structural characteristics of the Piatã grass.

\begin{tabular}{|c|c|c|c|c|c|c|c|c|}
\hline \multirow[b]{2}{*}{ Variable } & \multicolumn{3}{|c|}{ Fertilization } & \multicolumn{3}{|c|}{ Defoliation Frequency } & \multirow[b]{2}{*}{$\begin{array}{c}\text { P-value } \\
\text { Interaction }\end{array}$} & \multirow[b]{2}{*}{ SEM } \\
\hline & 100 & 200 & P-value & 28 & 35 & P-value & & \\
\hline${ }^{1}$ LBL & 13.38 & 14.26 & 0.152 & 14.35 & 13.29 & 0.092 & 0.711 & 0.317 \\
\hline${ }^{2} \mathrm{NL}$ & 4.50 & 4.33 & 0.630 & $4.83^{\mathrm{a}}$ & $4.00^{b}$ & 0.036 & 0.630 & 0.192 \\
\hline${ }^{3}$ LTB & 26.66 & 26.50 & 0.960 & 24.83 & 28.33 & 0.315 & 0.960 & 1.48 \\
\hline${ }^{4}$ DTB & 5.33 & 5.83 & 0.691 & 4.83 & 6.33 & 0.251 & 0.894 & 0.570 \\
\hline${ }^{5} \mathrm{LS}$ & 18.33 & 16.16 & 0.557 & 15.83 & 18.60 & 0.446 & 0.618 & 1.62 \\
\hline${ }^{6} \mathrm{DS}$ & 5.00 & 4.50 & 0.643 & 4.00 & 5.50 & 0.187 & 0.643 & 0.509 \\
\hline${ }^{7} \mathrm{RS}$ & 0.833 & 2.00 & 0.392 & 1.00 & 1.83 & 0.536 & 0.708 & 0.596 \\
\hline
\end{tabular}

${ }^{1}$ Leaf blade length $(\mathrm{cm}) ;{ }^{2}$ number of leaves (leaves tiller $\left.{ }^{-1}\right){ }^{3}$ population density of live tiller bases $\left(\right.$ LTB $\left.\mathrm{m}^{-2}\right) .{ }^{4}$ dead tiller bases (DTB $\mathrm{m}^{-2}$ ). ${ }^{5}$ live shoots $\left(\right.$ LS $\left.\mathrm{m}^{-2}\right) .{ }^{6}$ dead shoots (DS $\mathrm{m}^{-2}$ ); and ${ }^{7}$ reprodutive shoots (RS $\mathrm{m}^{-2}$ ); SEM: standard error of the mean; P-value: probability of a significant effect. Means followed by the same lower-case letters in the row differ by the Tukey test at $5 \%$ probability.

Table 5. Production of forage mass (FM, $t \mathrm{DM} \mathrm{ha}^{-1}$ ), relative composition of morphological components (\%) and leaf:stem ratio (L:S) of Piatã grass swards.

\begin{tabular}{ccccccccccc}
\hline & \multicolumn{3}{c}{ Fertilization } & & \multicolumn{3}{c}{ Defoliation Frequency } & & \\
\cline { 2 - 4 } Variable & 100 & 200 & P-value & & 28 & 35 & P-value & $\begin{array}{c}\text { P-value } \\
\text { Interaction }\end{array}$ & SEM \\
\hline FM & 6.31 & 6.93 & 0.283 & & 6.33 & 6.91 & 0.308 & 0.976 & 0.262 \\
Leaves & 77.43 & 77.18 & 0.865 & & 76.60 & 78.01 & 0.349 & 0.660 & 0.652 \\
Pseudostem & 16.08 & 16.65 & 0.591 & & 15.53 & 17.2 & 0.138 & 0.974 & 0.506 \\
Dead & 4.26 & 4.51 & 0.776 & & $5.56^{\mathrm{a}}$ & $3.21^{\mathrm{b}}$ & 0.024 & 0.560 & 0.514 \\
Inflorescence & 5.08 & 3.88 & 0.183 & & $5.83^{\mathrm{a}}$ & $3.13^{\mathrm{b}}$ & 0.011 & 0.587 & 0.571 \\
L:S & 4.91 & 4.63 & 0.497 & & 4.95 & 4.60 & 0.405 & 0.903 & 0.183 \\
\hline
\end{tabular}

SEM: standard error of the mean; P-value: probability of a significant effect. Means followed by the same lower-case letters in the row differ by the Tukey test at $5 \%$ probability.

With respect to the other structural characteristics involving the tillering dynamics (Table 4), all the types of tillers (basal, aerial, live, dead or reproductive) behaved similarly. The presence of inflorescences was only noted in the months of February and March for the two defoliation frequencies (28 and 35 days) and nitrogen levels (100 and $200 \mathrm{~kg} \mathrm{ha}^{-1}$ ), while the IL levels were close (93\% versus $96 \%$ ), respectively.

For the agronomic variable FM (Table 5), doubling the nitrogen dose to $200 \mathrm{~kg} \mathrm{~N} \mathrm{ha}^{-1}$ did not have a significant effect on total DM production, i.e., regardless of the $\mathrm{N}$ level, the FM remained relatively constant during the experimental period. These results indicate that $100 \mathrm{~kg} \mathrm{~N} \mathrm{ha}^{-1}$ was the maximum quantity that the grass was able to transform into FM when applied in a single high dose.
It has long been recognized that increased doses of nutrients, especially sources of $\mathrm{N}$, accelerate the accumulation of herbage (MAZZANTI; LEMAIRE, 1994; PACIULLO et al., 2016), in particular increasing the elongation of stems, a component that can reduce the nutritional value of the herbage, besides forming a physical barrier to defoliation (EUCLIDES et al., 2008; ZANINI et al., 2012b), but this was not observed in our experiments.

This contrasting result can be attributed to the method used in this work, with application of a single high dose of $\mathrm{N}$. However, there were no differences $(P>0.05)$ in SER, LAR, Phylloc and LL. Only LEL and NLL were altered, in favor of defoliation after 28 days, and the number of tillers remained unchanged (Table 4 ).

With respect to production of tillers, according to Barbosa et al. (2011), Barbosa et al. 
(2012) and Montagner et al. (2011), management strategies that aim to prolong the lifetime of tiller and leaf blade hamper the accumulation of biomass, since in older tillers the morphogenic variables that contribute to biomass yield are generally lower. However, the production of forage (FM; Table 5) was apparently high, because the swards had IL rates of 90 to $95 \%$ (DAVIES, 1993), indicating that in Piatã grass pastures submitted to high $\mathrm{N}$ doses generate heavier tillers with management practices that control defoliation.

Since there was no gradual increase in DM yield by adding more $\mathrm{N}$, it is evident that application of a single dose of $200 \mathrm{~kg} \mathrm{~N} \mathrm{ha}^{-1}$ is not economically advisable in comparison to $100 \mathrm{~kg} \mathrm{~N}$ $\mathrm{ha}^{-1}$, which kept the FM at a level considered good for the four months studied in the rainy season, when precipitation was normal (Figure 1), permitting five defoliations at 28-day intervals or four at 35-day intervals. Possibly factors such as the $4,32 \%$ OM in the soil (Table 1), presence of moisture (Figure 1), moment of application (in the late afternoon), faster decomposition of dead material and some residual effect of the $\mathrm{N}$ applied contributed to these results.

The percentages of the morphological components of the swards (Table 5) were not affected by the $\mathrm{N}$ application: there was a high proportion of LB (97\%), low S (16\%) and high L:S ratio (4.77), explaining the high LAI values obtained (Table 2). Only the short defoliation interval (28 days) presented higher proportion $(P<0.05)$ of senescent forage mass and inflorescence. Although significant, the increases of these undesirable fractions were $2 \%$ for dead material and $2.70 \%$ for inflorescence, respectively equivalent to increases of $155.57 \mathrm{~kg}$ and $178.7 \mathrm{~kg}$ of DM. These values would not be sufficient to compromise the nutritional value of the grass if defoliated sooner.

When managing pastures with light interception near 95\%, the LAI value reaches a critical level, when accumulation of leaf blade mass predominates, allowing a higher L:S ratio (HODGSON, 1990). But when IL is below 95\%, the maximum production of leaf blade was not reached, allowing greater participation of dead material in relation to total biomass (BARBOSA et al., 2007; ZANINI et al., 2012a).

Considering all the variables, it was evident that the results of the management strategies with cutting intervals of 28 and 35 days depended on the cutting height of $20 \mathrm{~cm}$. This defoliation intensity allowed sufficient IL (near 95\%) for the different types of tillers and resulted in plants with constant/uniform morphological components in all the cuttings, while the shorter cutting interval provided better pasture cycling.

Managing the IL can be used as a strategy, but it is not a practical technique, while sward height, besides being a nondestructive method, is easy to measure and has a strong relationship with IL (BARBOSA et al., 2007; HODGSON, 1990). Because of this, as suggested by Nantes et al. (2013), Piatã grass pastures can be managed with height near $30 \mathrm{~cm}$ (Table 2), because the production of leaf blades is not compromised (Table 5).

The application of a single high dose of nitrogen did not increase the number of tillers, but it did raise the individual weight of tillers without affecting the morphogenic and morphologic characteristics of the grass.

\section{Conclusion}

For Piatã grass pastures established in soils with good fertility, we recommend using 20 $\mathrm{cm}$ as the minimum cutting or grazing height, and defoliation frequency of 28 days with height of approximately $30 \mathrm{~cm}$.

In established pastures, if the desire is to reduce the fractioning of the $\mathrm{N}$ dose in the rainy season, we recommend applying a single dose of up to $100 \mathrm{~kg}$ of $\mathrm{N} \mathrm{ha}{ }^{-1}$ immediately after the first cutting.

\section{References}

BARBOSA, R. A.; NASCIMENTO JÚNIOR, D. D.; VILELA, H. H., SILVA, S. C. D.; EUCLIDES, V. P. B.; SBRISSIA, A. F.; SOUSA, B. M. D. L. Morphogenic and structural characteristics of guinea grass pastures submitted to three frequencies and two defoliation severities. Revista Brasileira de Zootecnia, v.40, n.5, p.947-954, 2011. https://doi.org/10.1590/S151635982011000500002 .

BARBOSA, R. A.; NASCIMENTO JÚNIOR, D. D.; VILELA, H. H.; SOUSA, B. M. D. L.; SILVA, S. C. D., EUCLIDES, V. P. B.; SILVEIRA, M. C. T. D. Morphogenetic and structural characteristics of guinea grass tillers at different ages under intermittent stocking. Revista Brasileira de Zootecnia, v.41, n.7, p.1583-1588, 2012. https://doi.org/10.1590/S1516$\underline{35982012000700005}$ 
BARBOSA, R.A.; NASCIMENTO JÚNIOR, D.D.; EUCLIDES, V.P.B.; SILVA, S.D.; ZIMMER, A.H.; TORRES JÚNIOR, R.D.A. Capim-tanzânia submetido a combinações entre intensidade e freqüência de pastejo. Pesquisa Agropecuária Brasileira, v. 42, n. 3, p. 329-340, 2007.

CHAPMAN, D.F.; LEMAIRE, G. Morphogenetic and structural determinants of plant regrowth after defoliation. In: BAKER, M.J. (Ed.) Grasslands for our world. Wellington: SIR Publishing, 1993. p.5564.

DAVIES, A. Tissue turnover in the sward. Sward measurement handbook. London: British Grassland Society, 1993. p. 183-216.

DEREGIBUS, V.A.; SANSHEZ, R.A.; CASAL, J.J. et al. Tillering responses to enrichment of red light beneath the canopy in humid natural grassland. Journal of Applied Ecology, v.22, p.199-206, 1985. https://doi.org/10.2307/2403337

DIFANTE, G. D. S., NASCIMENTO JÚNIOR, D. D., SILVA, S. C. D., EUCLIDES, V. P. B., MONTAGNER, D. B., SILVEIRA, M. C. T. D.; PENA, K. D. S. Morphogenetic and structural characteristics of marandu palisadegrass subjected to combinations of cutting heights and cutting intervals. Revista Brasileira de Zootecnia, v. 40, n.5, p.955-963, 2011. https://doi.org/10.1590/S1516$\underline{35982011000500003}$

EUCLIDES, V. P. B.; MACEDO, M. C. M.; DO VALLE, C. B.; BARBOSA, R. A.; GONÇALVES, W. V. Produção de forragem e características da estrutura do dossel de cultivares de Brachiaria brizantha sob pastejo. Pesquisa Agropecuária Brasileira, v.43, n.12, p.1805-1812, 2008. https://doi.org/10.1590/S0100-

204X2008001200023.

GASTAL, F; LEMAIRE, G. Defoliation, shoot plasticity, sward structure and herbage utilization in pasture: Review of the underlying ecophysiological processes. Agriculture, v. 5, n. 4, p.1146-1171, 2015. https://doi.org/10.3390/agriculture5041146

HODGSON, J. Grazing management: science into practice. New York: John Wiley and Sons, 1990. $203 p$.
LARA, M. A. S.; PEDREIRA, C. G. S. Respostas morfogênicas e estruturais de dosséis de espécies de Braquiária à intensidade de desfolhação. Pesquisa Agropecuária Brasileira, v. 46, n. 7, p. 760-767, 2011. https://doi.org/10.1590/S0100204X2011000700012.

LEMAIRE, G.; AGNUSDEI, M. Leaf tissue turn-over and efficiency of herbage utilization. In: LEMAIRE, G.; HODGSON, J.; MORAES, A. et al. (Eds.) Grassland ecophysiology and grazing ecology. Wallingford: CAB International, 2000. p.265-288. https://doi.org/10.1079/9780851994529.0265

LEMAIRE, G.; CHAPMAN, D. Tissue flows in grazed plant communities. In: HODGSON, J.; ILLIUS, A.W. (Eds.) The ecology and management of grazing systems. Wallingford: CAB International, 1996. p.3-36.

LEMAIRE, G.; SILVA, S. C.; AGNUSDEI, M.; WADE, M.; HODGSON, J. Interactions between leaf lifespan and defoliation frequency in temperate and tropical pastures: a review. Grass and Forage Science, v.64, n.4, p.341-353, 2009. https://doi.org/10.1111/j.1365-

2494.2009.00707.x.

MAZZANTI, A.; LEMAIRE, G. Effect of nitrogen fertilization on herbage production of tall fescue swards continuously grazed by sheep. 2 . Consumption and efficiency of herbage utilization. Grass and forage Science, v.49, n.3, p.352-359, 1994. https://doi.org/10.1111/i.13652494.1994.tb02010.x

MONTAGNER, D. B.; NASCIMENTO JÚNIOR, D. D.; SOUSA, B. M. D. L.; VILELA, H. H.; EUCLIDES, V. P. B.; SILVA, S.C. D.; CARLOTO, M. N. Morphogenetic and structural characteristics of tillers of guinea grass of different age and grazing severities. Revista Brasileira de Zootecnia, v.40, n.10, p.2105-2110, 2011. http://dx.doi.org/10.1590/S151635982011001000006

NANTES, N. N.; EUCLIDES, V. P. B.; MONTAGNER, D. B.; LEMPP, B.; BARBOSA, R. A.; GOIS, P. O. D. Animal performance and sward characteristics of piatã palisade grass pastures subjected to different grazing intensities. Pesquisa Agropecuária Brasileira, v.48, n.1, p.114-121, $2013 . \quad$ http://dx.doi.org/10.1590/S0100$\underline{204 \times 2013000100015}$ 
PACIULLO, D. S. C.; GOMIDE, C. D. M.; CASTRO, C. R. T.; MAURÍCIO, R. M.; FERNANDES, P. B.; MORENZ, M. J. F. Morphogenesis, biomass and nutritive value of Panicum maximum under different shade levels and fertilizer nitrogen rates. Grass and Forage Science, v. 72, n. 3, p.590-600, 2016.

https://doi.org/10.1111/gfs.12264

R CORE TEAM. R: A language and environment for statistical computing. Vienna, Austria: R Foundation for Statistical Computing, 2014.

SBRISSIA, A.F.; SILVA, S.C. O ecossistema de pastagens e a produção animal. In: MATTOS, W.R.S. (Ed.). A produção animal na visão dos Brasileiros. Piracicaba: Sociedade Brasileira de Zootecnia, 2001. p.731-754.

ZANINI, G. D.; SANTOS, G. T.; SBRISSIA, A. F. Frequencies and intensities of defoliation in Aruana Guineagrass swards: accumulation and morphological composition of forage. Revista Brasileira de Zootecnia, v. 41, n. 4, p. 905-913, 2012a. https://doi.org/10.1590/S1516$\underline{35982012000400011}$

ZANINI, G. D.; SANTOS, G. T.; SCHMITT, D.; PADILHA, D. A.; SBRISSIA, A. F. Distribuição de colmo na estrutura vertical de pastos de capim Aruana e azevém anual submetidos a pastejo intermitente por ovinos. Ciência Rural, v. 42, n. 5, p.882-887, 2012b.

https://doi.org/10.1590/S010384782012000500020. 